"Barriers and potential solutions for MSMEs in developing economies: Evidence from India"

\begin{tabular}{|c|c|c|}
\hline AUTHORS & \multicolumn{2}{|l|}{$\begin{array}{l}\text { Bishwajeet Prakash (D) } \\
\mathbb{R} \\
\text { Indrajit Kumar (D) } \\
\text { Jainendra Kumar Verma (iD) }\end{array}$} \\
\hline ARTICLE INFO & \multicolumn{2}{|c|}{$\begin{array}{l}\text { Bishwajeet Prakash, Indrajit Kumar and Jainendra Kumar Verma (2021). Barriers } \\
\text { and potential solutions for MSMEs in developing economies: Evidence from } \\
\text { India. Problems and Perspectives in Management, 19(4), 325-337. } \\
\text { doi:10.21511/ppm.19(4).2021.26 }\end{array}$} \\
\hline DOI & \multicolumn{2}{|c|}{ http://dx.doi.org/10.21511/ppm.19(4).2021.26 } \\
\hline RELEASED ON & \multicolumn{2}{|l|}{ Thursday, 02 December 2021} \\
\hline RECEIVED ON & \multicolumn{2}{|l|}{ Thursday, 16 September 2021} \\
\hline ACCEPTED ON & \multicolumn{2}{|l|}{ Monday, 22 November 2021} \\
\hline LICENSE & \multicolumn{2}{|c|}{$\begin{array}{l}\text { This work is licensed under a Creative Commons Attribution } 4.0 \text { International } \\
\text { License }\end{array}$} \\
\hline JOURNAL & \multicolumn{2}{|c|}{ "Problems and Perspectives in Management" } \\
\hline ISSN PRINT & \multicolumn{2}{|l|}{$1727-7051$} \\
\hline ISSN ONLINE & \multicolumn{2}{|l|}{$1810-5467$} \\
\hline PUBLISHER & \multicolumn{2}{|c|}{ LLC "Consulting Publishing Company "Business Perspectives" } \\
\hline FOUNDER & \multicolumn{2}{|c|}{ LLC "Consulting Publishing Company "Business Perspectives" } \\
\hline$\sigma^{0}$ & $B$ & ニ泣 \\
\hline NUMBER OF REFERENCES & NUMBER OF FIGURES & NUMBER OF TABLES \\
\hline 72 & 0 & 16 \\
\hline
\end{tabular}

(c) The author(s) 2022. This publication is an open access article. 


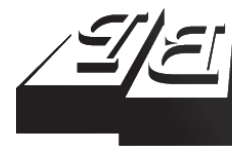

BUSINESS PERSPECTIVES

O

LLC "CPC "Business Perspectives"

Hryhorii Skovoroda lane, 10,

Sumy, 40022, Ukraine

www.businessperspectives.org
Received on: $16^{\text {th }}$ of September, 2021 Accepted on: 22 $2^{\text {nd }}$ of November, 2021 Published on: $2^{\text {nd }}$ of December, 2021

(c) Bishwajeet Prakash, Indrajit Kumar, Jainendra Kumar Verma, 2021

Bishwajeet Prakash, Dr., Assistant Professor (Guest), Department of Financial Studies \& Business Economics, South Campus University of Delhi, India. (Corresponding author)

Indrajit Kumar, Dr., Assistant Professor, Department of Management Studies, MVJ College of Engineering (Autonomous), India.

Jainendra Kumar Verma, Dr., Assistant Professor, Department of Economics, Central University of Punjab, India.
This is an Open Access article distributed under the terms of the Creative Commons Attribution 4.0 International license, which permits unrestricted re-use, distribution, and reproduction in any medium, provided the original work is properly cited.

Conflict of interest statement: Author(s) reported no conflict of interest

\section{BARRIERS AND POTENTIAL SOLUTIONS FOR MSMES IN DEVELOPING ECONOMIES: EVIDENCE FROM INDIA}

\begin{abstract}
Micro, small and medium enterprises (MSMEs) have emerged as an accelerator of economic growth with a sizeable contribution in job creation, innovation development, and reduction of regional disparities in most world economies. This paper investigates the influence of external and internal factors affecting the growth of MSMEs in poor-performing Bihar state, India. The objective of the study is to identify the major deep-rooted causes for the inability of MSMEs to compete in developing states and identify potential solutions. The study is based on an empirical database; it tested various dimensions of MSMEs barriers in their potential growth. The target group included MSMEs of Bihar state, India, using a sample of 450 entrepreneurs. The paper adopted a multistage stage sampling and multivariate analysis technique. The results showed that there are twelve major potential barriers, both endogenous and exogenous, faced by MSMEs, such as availability of raw materials, financial issues, labor force challenges, technology inefficiency, power/electricity scarcity, poor marketing, competition, knowledge-related challenges, government and administration problems, infrastructure inefficiency, etc. The findings show that these barriers affect the promotion and growth of MSMEs in developing regions. In future, it is suggested to focus on the implementation of good governance that helps to remove effectively the major barriers of MSMEs in underdeveloped states, such as Bihar, India.
\end{abstract}

\section{Keywords}

Bihar, small industries, barriers approach, effective solutions, entrepreneurship, infrastructure, external and internal factors

\section{JEL Classification $\quad$ L26, L53, O18, R00}

\section{INTRODUCTION}

The micro, small and medium enterprises (MSMEs) sector has been recognized as the most important pillar of the economy. It plays a vital role in developing and developed economies of the world. These enterprises work as the backbone and are essential for the economic potential growth and development of countries (Stel et al., 2005; Beck et al., 2005; Acs et al., 2008a, 2008b). In India, with lofty discrepancies between rich and poor in conjunction with a problem of unemployment, MSMEs are amongst the key drivers of economic development, innovation, and employment (RBI, 2019). MSMEs sector is characterized by low investment, higher employment opportunities, operational flexibility, reduction of disparities, and import substitution (Singla \& Grover, 2012). MSMEs sector has a vast network with expansion throughout the country with 633.8 lakh enterprises offering 1,200 lakh of employment opportunities (Ministry of Micro Small and Medium Enterprises, 2018). The contribution of MSMEs to the economy consists of $90 \%$ of enterprises, $80 \%$ of the non-agriculture labor force, $6.11 \%$ of GDP manufacturing, $24 \%$ of GDP service sector, $33.4 \%$ in manufacturing activities, and $45 \%$ in total export (Confederation of Indian Industry, 2019). 
SMEs play a crucial role in all the economies that have been acknowledged. SMEs ventures/entrepreneurs/owners face many obstacles that limit the long-run survival (Kamunge et al., 2014). Barriers for MSMEs lead to a high failure rate or becoming sick at the initial age (Smallbone \& Rogut, 2005). The barriers can be both endogenous and exogenous. Internal barriers include management inefficiency, ineffective planning, and bookkeeping (Smith \& Smith, 2007; Kambwale et al., 2015). External barriers include poor infrastructure, government policy, access to raw materials, and delayed payments from creditors (Smith \& Smith, 2007; Nongnit, 2011). Thus, barriers, motivational factors, and problems uncounted by SMEs throughout the world called attention of numerous researchers from various countries (Anderson \& Pomfret, 2001; Temtime \& Pansiri, 2006; Baron \& Shane, 2007; Manzur \& Nayeem, 2008; Olawale \& Garwe, 2010; Bartlett \& Bukvic, 2001; Shaw \& Williams, 2009; Gray, 2006; Krasniqi, 2010; Omerzel \& Antoncic, 2008; Hoque \& Biswas, 2014; Kang, 2012; Salikin et al., 2014; Blossom \& Said, 2014; Ramukumba, 2014; Dasanayaka et al., 2017; Benzing et al., 2019).

\section{LITERATURE REVIEW}

In this study, MSMEs have been classified and identified as per investment in equipment or machinery, according to the official definition of the Ministry of Micro, Small and Medium Enterprises, India. Such enterprises are defined for the manufacturing sector in terms of their investments into equipment and production (costs for pollution prevention, $\mathrm{R} \& \mathrm{D}$, industrial safety, etc., are not included) to the investment limit maximum up to Rs. 25 lakh for micro, up to Rs. 25 lakh Rs. 5 crores for small, up to Rs. 5 crores to Rs. 10 crores for medium enterprises, and service sector regarding investment in equipment with a maximum of Rs. 10 lakh for micro, up to Rs. 2 crores for small, and Rs. 5 crores for medium Enterprises (Ministry of Micro Small and Medium Enterprises, 2006). There is evidence that MSMEs are positively linked with economic growth, per capita income, and improvement of living conditions in low-income countries and regions (Acs et al., 2008b). The business activities of SMEs are a dynamic process for economic development as they help to generate employment, innovation, and promote local welfare (Acs et al., 2008a). According to van Praag and Versloot (2007), based on the study of 57 publications, it was concluded that entrepreneurship is vital for the economy as it creates huge employment opportunities, promotes innovation and economic growth of the country. Thus, MSMEs contribute to the economic well-being of the middle class, reducing regional disparities in the economy, promoting local entrepreneurship, and improving living standards (Chen, 2006; Pissarides, 1999). MSMEs provide huge complementary work to large organizations, serve as basic raw materials providers, and provide economic stimulus competitively (Longenecker et al., 1997). In Bihar state, 99\% of enterprises fall into the segment of MSMEs and in terms of employment, 147,775 people are engaged in MSMEs enterprises (Prakash, 2019). However, this sector has great potential for the country's economic growth, but these enterprises have to face numerous limitations and obstacles in their establishment, promotion, maintenance, and expansion of their ventures.

Barriers, challenges, and obstacles, faced by SMEs and MSMEs, are presented in Table 1.

Table 1. Conceptual literature review

\begin{tabular}{l|c}
\hline \multicolumn{1}{c}{ Barriers } & References \\
\hline Technology inefficiency & Pribadi and Kanai (2011); Siringoringo et al. (2009); Mutula and Brakel (2007) \\
\hline Financial access & Ardic et al. (2011); Olawale and Garwe (2010); Hartungi (2007); OECD (2009) \\
Access to raw materials & Tambunan (2009); Siringoringo et al. (2009); Hamisi (2011) \\
Management skill & Olawale and Garwe (2010); Das et. al (2007) \\
Government, regulation, and institutional & Pribadi and Kanai (2011); Tambunan (2009); Al-Hyari et al. (2011); Olawale and Garwe \\
policies & (2010) \\
Competition & Siringoringo et al. (2009) \\
Infrastructure inefficiency & Lawrence and Tar (2010); Olawale and Garwe (2010); Siringoringo et al. (2009) \\
\hline Transportation inefficiency & Tambunan (2009); Hamisi (2011); Siringoringo et al. (2009); Torri (2012) \\
Managerial capacity & OECD (2009) \\
\hline
\end{tabular}


Table 1 (cont.). Conceptual literature review

\begin{tabular}{|c|c|}
\hline Barriers & References \\
\hline Quantity restriction & Hussain (2004) \\
\hline Procurement of raw material & Abushgra and Bach (2013); Prakash and Verma (2019) \\
\hline Skilled labor scarcity & Abushgra and Bach (2013) \\
\hline Labor unrest & Bihari (2011) \\
\hline Power tariff & Das et al. (2007) \\
\hline Lack of access to packaging technologies & Lokhande (2014) \\
\hline Absence of workforce planning & Lokhande (2014) \\
\hline Lack of proper distribution system & Lokhande (2014) \\
\hline Poor marketing & Choudhary (2012) \\
\hline Improper accounting systems & Goswami et al. (2017) \\
\hline High labor cost & Tambunan (2009) \\
\hline Absenteeism & Thayumanavar and Kavitha (2019) \\
\hline Inadequate wages and salary & Thayumanavar and Kavitha (2019) \\
\hline Lack of demand & Chandraiah and Vani (2014) \\
\hline Domestic problems of entrepreneurs & Salikin et al. (2014) \\
\hline Natural calamities & Mallikarjunaiah and Sudarsan (2012) \\
\hline Delay payments from creditors & Chandraiah and Vani (2014) \\
\hline
\end{tabular}

\section{AIMS AND HYPOTHESES}

This study aims to provide empirical evidence and analyze the factors affect the potential growth of the MSMEs in the developing economies states. The study includes major barriers and constraints faced by MSMEs in underdeveloped states like Bihar, India as well develop the relationship between organizational structure and barriers in operation of MSMEs in state.

Based on the existing literature, following hypotheses have been developed:

$H_{1}$ : Availability of raw materials, financial access, labor issues, technology inefficiency, power tariff, poor marketing, infrastructure inefficiency, competition, knowledge transfer, poor management, and other problems are major barriers for the MSMEs growth in the developing state of Bihar, India.

$\mathrm{H}_{2}: \quad$ Education qualification, gender and industries classification do not significant influence the MSMEs performance in the State.

\section{METHODOLOGY}

This study evaluates the severity of the impact of the major barriers in the growth of MSMEs in Bihar state, India. Major obstacles to the growth of MSMEs are erratic power supply, shortage of raw materials, fall in demand, non-availability of credit, non-availability of labor, labor disputes, etc. (Ministry of Micro Small and Medium Enterprises, 2018). After conducting a literature review and preliminary investigation, a semi-structured schedule was designed and personal interviews were conducted with owners/managers of MSMEs in Bihar. A total of 54 variables were identified and these variables were classified into 12 major categories of barriers. The survey includes all the three sections of MSMEs (micro, small and medium enterprises) with all age groups, gender, and various industries. 65 questions based on the developed concept and literature review were distributed among respondents. A 5-point Likert scale was used where ' 1 ' stands for strongly disagree and ' 5 ' stands for strongly agree (Brace, 2008). The schedule used for the study was pretested (pilot tested) among 10\% of MSME owners/managers. According to their feedback and comments, a revised schedule was delivered to the rest $90 \%$ of MSME owners/managers in Bihar, India.

However, a total of 450 samples were collected through a stratified random sampling method. From the pilot survey, it was discovered that there were sixty-five problems identified as barriers for the MSME growth in Bihar. These sixty-five questions were classified into 12 groups according to their nature. The collected data were scrutinized and processed through the use of IBM SPSS ver- 
sion 25 to quantify the reliability and normality of the data set. The data collection was conducted in the period from January 2018 to March 2019, in person. The paper uses mean and standard deviation, $\mathrm{t}$-test, and ANOVA test. Table 2 shows the demographic characteristics of MSME owners/ managers in the state of Bihar.

Table 2. Demographic characteristics

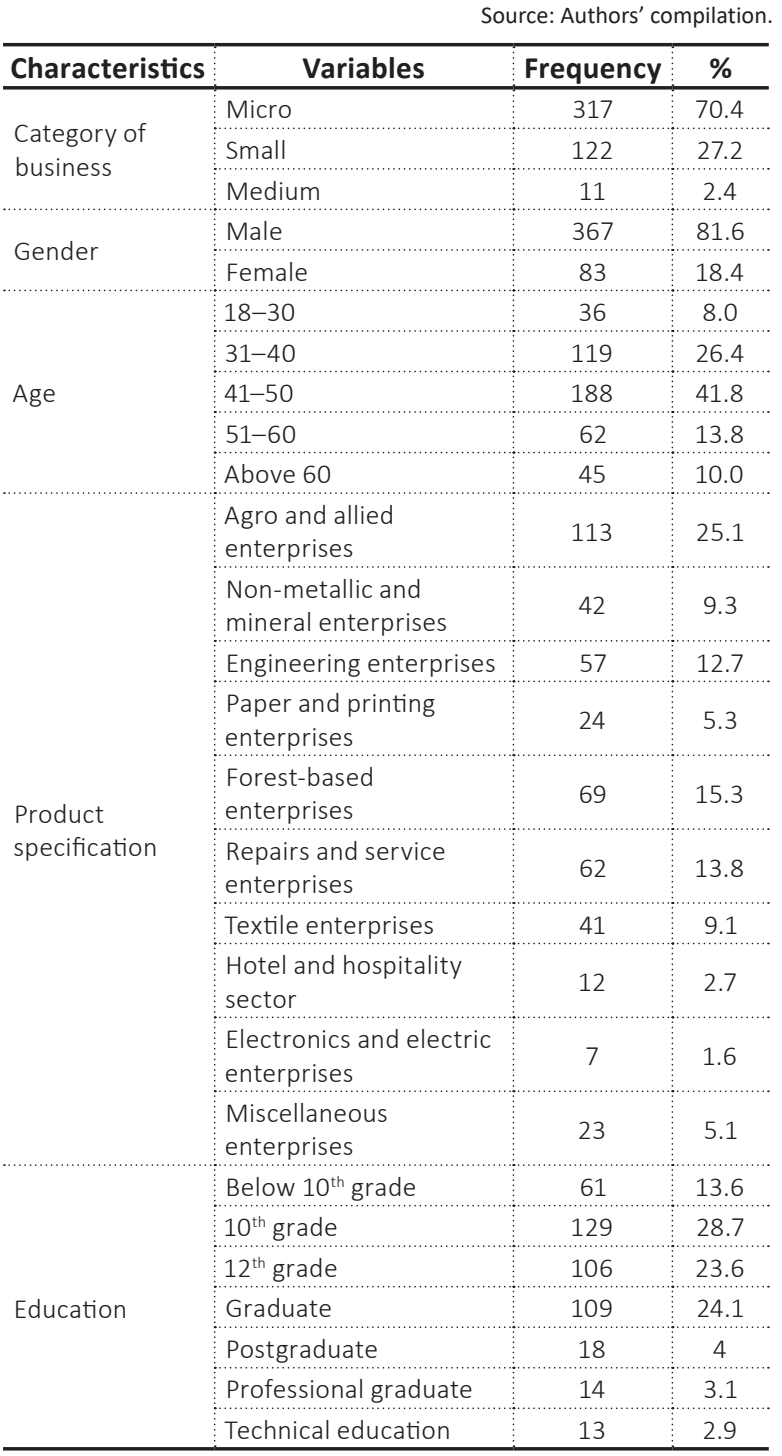

The demographic structure included gender, age, type of business, education level, and product specification. Industry sector includes micro (70.40\%), small (27.2\%), and medium (27.2\%) enterprises. Most of the owners/managers were male (81.6\%) and the majority were $31-40$ years old (41.8\%). As for industry classification, maximum enterprises belong to agro, food, and allied-based enterprises - 113 (25.1\%). The main education qualification was below graduate.

\section{RESULTS AND DISCUSSION}

Primary data were collected to examine barriers to the potential growth of MSMEs in Bihar. First, the reliability test was conducted; it was found that all data were normal and Cronbach's value was more than 0.60, which was appropriate for further study (Urbach \& Ahlemann, 2010; Hair et al., 2011). Second, problems were categorized; variables with their mean values and t-values were used to test the significance. The major barriers results are further discussed.

Raw material challenges. The literature review revealed that MSME owners/managers faced the problems related to raw materials availability. This study was not an exception. Table 3 shows that there is untimely availability of raw materials $(\overline{\mathrm{x}}=3.26, \mathrm{t}=4.793, \mathrm{p}<.05)$, variation in price of raw materials $(\overline{\mathrm{x}}=3.42, \mathrm{t}=9.516, \mathrm{p}<.05)$, high price of raw materials $(\overline{\mathrm{x}}=3.82, \mathrm{t}=18.643, \mathrm{p}<.05)$, materials are not available locally $(\overline{\mathrm{x}}=3.50, \mathrm{t}=8.542$, $\mathrm{p}<.05)$, lack of finance for raw materials ( $\overline{\mathrm{x}}=3.50$, $\mathrm{t}=8.542, \mathrm{p}<.005)$ and faulty government policy $(\overline{\mathrm{x}}=3.41, \mathrm{t}=7.627, \mathrm{p}<.05)$. It was found that high cost of raw materials leads to the huge problems for owners/managers to operate their daily needs. This finding supports Tambunan (2009) and Siringoringo et al. (2009).

Table 3. Raw material challenges

Source: Authors' compilation.

\begin{tabular}{|c|c|c|c|c|}
\hline Problems & Mean & t-value & Significance & Result \\
\hline $\begin{array}{l}\text { Untimely availability } \\
\text { of raw materials }\end{array}$ & 3.26 & 4.793 & 0.00 & Rejected \\
\hline $\begin{array}{l}\text { Variation in prices for } \\
\text { raw materials }\end{array}$ & 3.42 & 9.516 & 0.00 & Rejected \\
\hline $\begin{array}{l}\text { High Price of raw } \\
\text { materials }\end{array}$ & 3.52 & 11.018 & 0.00 & Rejected \\
\hline $\begin{array}{l}\text { Materials are not } \\
\text { available locally }\end{array}$ & 3.50 & 8.542 & 0.00 & Rejected \\
\hline $\begin{array}{l}\text { Lack of finance for } \\
\text { raw materials }\end{array}$ & 3.82 & 18.643 & 0.00 & Rejected \\
\hline $\begin{array}{l}\text { Faulty government } \\
\text { policy }\end{array}$ & 3.41 & 7.627 & 0.00 & Rejected \\
\hline
\end{tabular}

Note: Cronbach's alpha $=.685 ;$ Normality = Normal.

Financial challenges. The finance is known as the blood for the MSMEs. The availability of timely and adequate finance at a reasonable rate is an essential requirement for the development of MSMEs 
in Bihar. Lack of finance can affect the fixed and working capital and thus owners/managers cannot modernize their MSMEs. Table 4 shows that there were several financial problems, namely shortage of fixed capital $(\overline{\mathrm{x}}=3.53, \mathrm{t}=11.388, \mathrm{p}<.05)$, shortage of working capital $(\overline{\mathrm{x}}=3.84, \mathrm{t}=20.77$, $\mathrm{p}$ $<.05)$, increase in product cost $(\overline{\mathrm{x}}=3.53, \mathrm{t}=12.371$, $\mathrm{p}<.05)$, delays in realization of bills $(\overline{\mathrm{x}}=3.63, \mathrm{t}=$ $14.171, \mathrm{p}<.05)$, sanctioning of the loan $(\overline{\mathrm{x}}=3.50, \mathrm{t}=$ $10.472, \mathrm{p}<.05)$, underfinancing $(\overline{\mathrm{x}}=3.16, \mathrm{t}=2.965$, $\mathrm{p}<.05)$, and delay in payments from creditors $(\overline{\mathrm{x}}=$ $3.87, \mathrm{t}=0.873, \mathrm{p}<.05)$. However, it was found that delay payments from creditors was highly responsible for financial problem of MSMEs in Bihar, supporting Rao et al. (2015).

Table 4. Financial challenges

Source: Authors' compilation.

\begin{tabular}{|c|c|c|c|c|}
\hline Problems & Mean & t-value & Significance & Result \\
\hline $\begin{array}{l}\text { Shortage of fixed } \\
\text { capital }\end{array}$ & 3.53 & 11.388 & 0.00 & Rejected \\
\hline $\begin{array}{l}\text { Shortage of working } \\
\text { capital }\end{array}$ & 3.84 & 20.770 & 0.00 & Rejected \\
\hline $\begin{array}{l}\text { Increase in product } \\
\text { cost }\end{array}$ & 3.53 & 12.371 & 0.00 & Rejected \\
\hline $\begin{array}{l}\text { Delays realization of } \\
\text { bills }\end{array}$ & 3.63 & 14.171 & 0.00 & Rejected \\
\hline $\begin{array}{l}\text { Sanctioning of the } \\
\text { loan }\end{array}$ & 3.50 & 10.472 & 0.00 & Rejected \\
\hline Underfinancing & 3.16 & 2.965 & 0.03 & Rejected \\
\hline $\begin{array}{l}\text { Delay payments from } \\
\text { creditors }\end{array}$ & 3.87 & 0.873 & 0.00 & Rejected \\
\hline
\end{tabular}

Note: Cronbach's alpha $=.704 ;$ Normality $=$ Normal .

Human resources challenges. Human resource management and hiring the labor was a vital component for the MSME growth in Bihar. Human resource management in the industries is most difficult tasks performed by entrepreneurs. Table 5 shows the main human resources problems, namely non-availability of skilled labor $(\overline{\mathrm{x}}=3.69$, $\mathrm{t}=13.127, \mathrm{p}<.05)$, non-availability of casual labor $(\overline{\mathrm{x}}=2.82, \mathrm{t}=-3.603, \mathrm{p}<.05)$, demand of high wages $(\overline{\mathrm{x}}=3.64, \mathrm{t}=12.476, \mathrm{p}<.05)$, low productivity/ low efficiency $(\overline{\mathrm{x}}=3.52, \mathrm{t}=11.181, \mathrm{p}<.05)$, absenteeism $(\overline{\mathrm{x}}=3.73, \mathrm{t}=14.269, \mathrm{p}<.05)$, inadequate wages and salary $(\overline{\mathrm{x}}=2.87, \mathrm{t}=-2.376, \mathrm{p}<.05)$ and labor unrest $(\overline{\mathrm{x}}=2.91, \mathrm{t}=-1.64, \mathrm{p}>.05)$. However, absenteeism was the major hurdle for the MSMEs in Bihar; these concerns were raised by Bartlett and Bukvic (2001).
Table 5. Human resource challenges

Source: Authors' compilation.

\begin{tabular}{|c|c|c|c|c|}
\hline Problems & Mean & t-value & Significance & Result \\
\hline $\begin{array}{l}\text { Non-availability of } \\
\text { skilled labor }\end{array}$ & 3.69 & 13.127 & 0.00 & Rejected \\
\hline $\begin{array}{l}\text { Non-availability of } \\
\text { casual labor }\end{array}$ & 2.82 & -3.603 & 0.00 & Rejected \\
\hline $\begin{array}{l}\text { Demand for high } \\
\text { wages }\end{array}$ & 3.64 & 12.476 & 0.00 & Rejected \\
\hline $\begin{array}{l}\text { Low productivity/Low } \\
\text { efficiency }\end{array}$ & 3.52 & 11.181 & 0.00 & Rejected \\
\hline Absenteeism & 3.73 & 14.269 & 0.00 & Rejected \\
\hline $\begin{array}{l}\text { Inadequate wages } \\
\text { and salary }\end{array}$ & 2.87 & -2.376 & 0.01 & Rejected \\
\hline Labor unrest & 2.91 & -1.640 & 0.10 & Rejected \\
\hline
\end{tabular}

Note: Cronbach's alpha $=.714 ;$ Normality $=$ Normal.

Technology challenges. MSME owners/managers are not much aware of advanced technology of production, supplier, transportation, and marketing efficiency. Table 6 shows that there are some technology problems, namely indigenous machinery $(\overline{\mathrm{x}}=3.24, \mathrm{t}=4.02, \mathrm{p}<.05)$, imported machinery $(\overline{\mathrm{x}}=2.53, \mathrm{t}=-9.594, \mathrm{p}<.05)$, unsuitability of machinery $(\overline{\mathrm{x}}=2.83, \mathrm{t}=-2.999, \mathrm{p}<.05)$, testing facilities for raw material $(\overline{\mathrm{x}}=2.75, \mathrm{t}=5.211, \mathrm{p}<$ $.05)$, excess consumption of raw material $(\overline{\mathrm{x}}=3.18$, $\mathrm{t}=3.609, \mathrm{p}<.05)$, and excess consumption of power/fuel $(\overline{\mathrm{x}}=3.34, \mathrm{t}=6.719, \mathrm{p}<.05)$. The technological barriers in SMEs has been also supported by Siringoringo et al. (2009) and Mutula and Brakel (2007). However, excess consumption of power/fuel by machinery was the major obstacle for MSMEs.

Table 6. Technology challenges

Source: Authors' compilation.

\begin{tabular}{|c|c|c|c|c|}
\hline Problems & Mean & t-value & Significance & Result \\
\hline $\begin{array}{l}\text { Indigenous } \\
\text { machinery }\end{array}$ & 3.24 & 4.020 & 0.00 & Rejected \\
\hline Imported machinery & 2.53 & -9.594 & 0.00 & Rejected \\
\hline $\begin{array}{l}\text { Unsuitability of } \\
\text { machinery }\end{array}$ & 2.83 & -2.999 & 0.00 & Rejected \\
\hline $\begin{array}{l}\text { Testing facilities for } \\
\text { raw material }\end{array}$ & 2.75 & 5.211 & 0.00 & Rejected \\
\hline $\begin{array}{l}\text { Excess consumption } \\
\text { of raw material }\end{array}$ & 3.18 & 3.609 & 0.00 & Rejected \\
\hline $\begin{array}{l}\text { Excess consumption } \\
\text { of power/fuel }\end{array}$ & 3.34 & 6.719 & 0.00 & Rejected \\
\hline
\end{tabular}

Note: Cronbach's alpha $=.685 ;$ Normality = Normal.

Power supply challenges. An adequate and uninterrupted supply of electric power is an essential and crucial input for the efficient operation of smallscale enterprises. Table 7 shows the following pow- 
er supply problems: inadequate power supply $(\overline{\mathrm{x}}=$ $3.96, \mathrm{t}=20.775, \mathrm{p}<.05)$, power-cuts $(\overline{\mathrm{x}}=3.44, \mathrm{t}=$ $8.802, \mathrm{p}<.05)$, and high electricity charges $(\overline{\mathrm{x}}=$ $4.07, \mathrm{t}=25.042, \mathrm{p}<.05)$. According to the Reserve Bank of India (2019), production costs increase prices for products of SMEs due to inadequate power supply and high electricity charges.

Table 7. Power supply challenges

Source: Authors' compilation.

\begin{tabular}{|c|c|c|c|c|}
\hline Problems & Mean & t-value & Significance & Result \\
\hline $\begin{array}{l}\text { Inadequate power } \\
\text { supply }\end{array}$ & 3.96 & 20.775 & 0.00 & Rejected \\
\hline Power-cuts & 3.44 & 8.802 & 0.00 & Rejected \\
\hline $\begin{array}{l}\text { High electricity } \\
\text { charges }\end{array}$ & 4.07 & 25.042 & 0.00 & Rejected \\
\hline
\end{tabular}

Note: Cronbach's alpha $=.703 ;$ Normality $=$ Normal .

Marketing challenges. Marketing problems are found to be most challenging problems for MSMEs; they mostly arise due to lack of standardization, inadequate products and packaging designs, use of low-quality materials, lack of accuracy and inconsistency in the finishing and final products, and others, which affect globalization of products. Table 8 shows that there are different marketing challenges, namely high cost of marketing $(\overline{\mathrm{x}}=3.52, \mathrm{t}=11.463, \mathrm{p}<.05)$, inadequate sales promotion $(\overline{\mathrm{x}}=3.49, \mathrm{t}=11.294, \mathrm{p}<.05)$, improper distribution strategy $(\overline{\mathrm{x}}=2.48, \mathrm{t}=-13.341$, $\mathrm{p}<.05)$, untimely introduction of product $(\overline{\mathrm{x}}=2.53$, $\mathrm{t}=-11.277, \mathrm{p}<.005)$, high cost of advertisement $(\overline{\mathrm{x}}=$ $3.49, \mathrm{t}=10.542, \mathrm{p}<.05)$, and poor marketing strategy $(\overline{\mathrm{x}}=3.94, \mathrm{t}=21.636, \mathrm{p}<.05)$. These results are supported by Weaver and Pak (1990) and Moodley and Morris (2004). Thus, poor marketing strategy became the major concern for MSMEs in Bihar.

Table 8. Marketing challenges

Source: Authors' compilation.

\begin{tabular}{|c|c|c|c|c|}
\hline Problems & Mean & t-value & Significance & Result \\
\hline $\begin{array}{l}\text { High cost of } \\
\text { marketing }\end{array}$ & 3.52 & 11.463 & 0.00 & Rejected \\
\hline $\begin{array}{l}\text { Inadequate sales } \\
\text { promotion }\end{array}$ & 3.49 & 11.294 & 0.00 & Rejected \\
\hline $\begin{array}{l}\text { Improper distribution } \\
\text { strategy }\end{array}$ & 2.48 & -13.341 & 0.00 & Rejected \\
\hline $\begin{array}{l}\text { Untimely } \\
\text { introduction of } \\
\text { product }\end{array}$ & 2.53 & -11.277 & 0.00 & Rejected \\
\hline $\begin{array}{l}\text { High cost of } \\
\text { advertisement }\end{array}$ & 3.49 & 10.542 & 0.00 & Rejected \\
\hline $\begin{array}{l}\text { Poor marketing } \\
\text { strategy }\end{array}$ & 3.94 & 21.636 & 0.00 & Rejected \\
\hline
\end{tabular}

Note: Cronbach's alpha $=.698 ;$ Normality $=$ Normal.
Infrastructure challenges. The availability of adequate infrastructure has been a major requirement for the growth of SMEs; the movement of raw materials and distribution of products depend on an effective road and transportation system. The transportation problems include transportation cost, modes of transportation, low public transportation inconvenience due to different engaging modes of transport before the product is finally sent to the market. Table 9 shows that there are different infrastructure challenges, namely lack of public transport $(\overline{\mathrm{x}}=4.05, \mathrm{t}=23.748, \mathrm{p}<.05)$, high transport cost $(\overline{\mathrm{x}}=3.95, \mathrm{t}=21.548, \mathrm{p}<.05)$, poor quality of roads $(\overline{\mathrm{x}}=4.13, \mathrm{t}=-27.255, \mathrm{p}<.05)$, and poor quality of the drainage system $(\overline{\mathrm{x}}=3.93$, $\mathrm{t}=21.609, \mathrm{p}<.05)$. It was found that the poor quality of roads in Bihar is the major barrier to the growth of MSMEs.

Table 9. Road and transportation challenges

Source: Authors' compilation.

\begin{tabular}{l|c|c|c|c}
\hline \multicolumn{1}{c}{ Problems } & Mean & t-value & Significance & Result \\
\hline $\begin{array}{l}\text { Lack of public } \\
\text { transport }\end{array}$ & 4.05 & 23.748 & 0.00 & Rejected \\
\hline High transport cost & 3.95 & 21.548 & 0.00 & Rejected \\
\hline Poor quality of roads & 4.13 & 27.255 & 0.00 & Rejected \\
\hline $\begin{array}{l}\text { Poor quality of the } \\
\text { drainage system }\end{array}$ & 3.93 & 21.609 & 0.00 & Rejected \\
\hline
\end{tabular}

Note: Cronbach's alpha $=.693 ;$ Normality $=$ Normal.

Competition challenges. Huge competition is the most important problem faced by MSMEs in recent days. Owing to the increase in the number of similar products in the market, entrepreneurs have to take proper care to produce high-quality products with lower costs, due to huge competition with large enterprises in a country. Table 10 shows that there are competition from large enterprises $(\overline{\mathrm{x}}=2.73, \mathrm{t}=-4.613, \mathrm{p}<.05)$, established small industries in the region $(\overline{\mathrm{x}}=3.55$, $\mathrm{t}=11.9, \mathrm{p}<.05)$, established small industries in other regions $(\overline{\mathrm{x}}=3.57, \mathrm{t}=12.485, \mathrm{p}<.05)$, and competition from imported substitutes $(\overline{\mathrm{x}}=$ $3.35, \mathrm{t}=6.86, \mathrm{p}<.05)$. The stiff competition is faced by MSMEs in all stages of business (Mali, 1998; Bala, 2004). However, it was found that completion within MSMEs is a major concern for entrepreneurs. 
Table 10. Competition challenges

Source: Authors' compilation

\begin{tabular}{|c|c|c|c|c|}
\hline Problems & Mean & t-value & Significance & Result \\
\hline $\begin{array}{l}\text { Competition from large } \\
\text { enterprises }\end{array}$ & 2.73 & -4.613 & 0.00 & Rejected \\
\hline $\begin{array}{l}\text { Established small } \\
\text { industries in the region }\end{array}$ & 3.55 & 11.9 & 0.00 & Rejected \\
\hline $\begin{array}{l}\text { Established small } \\
\text { industries in other } \\
\text { regions }\end{array}$ & 3.57 & 12.485 & 0.00 & Rejected \\
\hline $\begin{array}{l}\text { Competition from } \\
\text { imported substitutes }\end{array}$ & 3.35 & 6.86 & 0.00 & Rejected \\
\hline
\end{tabular}

Note: Cronbach's alpha $=.675 ;$ Normality $=$ Normal.

Knowledge-related challenges. Different enterprises surveyed in the study have reported that ineffective knowledge leads to becoming significant problems for the industry. Table 11 shows that there are different associated challenges, namely lack of managerial skills $(\overline{\mathrm{x}}=3.5, \mathrm{t}=9.977, \mathrm{p}<.05)$, lack of accounting skills $(\overline{\mathrm{x}}=2.85, \mathrm{t}=-2.826$, $\mathrm{p}$ $\leq .05)$, and technical skills $(\overline{\mathrm{x}}=3.42, \mathrm{t}=8.188, \mathrm{p}$ $<.05)$. These findings support the idea that poor managerial skills among entrepreneurs is the main problem for MSMEs in Bihar. These results support McAdam and Reid (2001).

Table 11. Knowledge-related challenges

Source: Authors' compilation.

\begin{tabular}{|c|c|c|c|c|}
\hline Problems & Mean & t-value & Significance & Result \\
\hline $\begin{array}{l}\text { Lack of managerial } \\
\text { skills }\end{array}$ & 3.50 & 9.977 & 0.00 & Rejected \\
\hline $\begin{array}{l}\text { Lack of accounting } \\
\text { skills }\end{array}$ & 2.85 & -2.826 & 0.05 & Rejected \\
\hline $\begin{array}{l}\text { Lack of technical } \\
\text { skills }\end{array}$ & 3.42 & 8.188 & 0.00 & Rejected \\
\hline
\end{tabular}

Note: Cronbach's alpha $=.675 ;$ Normality $=$ Normal.

Government and administrative challenges. Political changes and administrative bottlenecks could affect the growth of MSMEs. The policy-making challenges are related to high taxation policy, high rate of interest, unfavorable investment climate; they create major barriers for the development and substantial growth of SMEs in India (Pribadi \& Kanai, 2011). Table 12 shows that there are several government and administrative problems like strict credit policy $(\overline{\mathrm{x}}=3.31, \mathrm{t}=6.37$, $\mathrm{p}<.05)$, unfavorable investments climate $(\overline{\mathrm{x}}=3.13$, $\mathrm{t}=2.754, \mathrm{p}>.05)$, and fear of nationalization $(\overline{\mathrm{x}}=$ $2.12, \mathrm{t}=-15.266, \mathrm{p}<.05)$. Thus, the high taxation policy of the government highly affects the growth of MSMEs in Bihar.
Table 12. Government and administrative challenges

Source: Authors' compilation.

\begin{tabular}{|c|c|c|c|c|}
\hline Problems & Mean & t-value & Significance & Result \\
\hline Strict credit policy & 3.31 & 6.370 & 0.00 & Rejected \\
\hline $\begin{array}{l}\text { Unfavorable } \\
\text { investments } \\
\text { climate }\end{array}$ & 3.13 & 2.754 & 0.06 & Fail to reject \\
\hline $\begin{array}{l}\text { Fear of } \\
\text { nationalization }\end{array}$ & 2.12 & -15.266 & 0.00 & Rejected \\
\hline $\begin{array}{l}\text { Restraints } \\
\text { restriction on } \\
\text { purchases }\end{array}$ & 3.40 & 8.723 & 0.00 & Rejected \\
\hline $\begin{array}{l}\text { Excessive taxation } \\
\text { policy of the } \\
\text { government }\end{array}$ & 3.54 & 12.455 & 0.00 & Rejected \\
\hline
\end{tabular}

Note: Cronbach's alpha $=.725 ;$ Normality $=$ Normal.

Management-related challenges. Poor project, personnel, and finance management leads enterprises to become sick. Table 13 shows such managerial problems as poor utilization of the assets $(\overline{\mathrm{x}}=3.57$, $\mathrm{t}=14.828, \mathrm{p}<.05)$, underutilization of installed capacity $(\overline{\mathrm{x}}=3.06, \mathrm{t}=1.336, \mathrm{p}>.05)$, inadequate material management $(\overline{\mathrm{x}}=3.42, \mathrm{t}=9.467, \mathrm{p}<.05)$, absence of product planning $(\overline{\mathrm{x}}=3.12, \mathrm{t}=2.433, \mathrm{p}$ $<.05)$, absence of manpower planning $(\overline{\mathrm{x}}=3.14, \mathrm{t}=$ $2.851, \mathrm{p}<.05)$, disputes among partners $(\overline{\mathrm{x}}=1.91$, $\mathrm{t}=-19.81, \mathrm{p}<.05)$, and lack of market research $(\overline{\mathrm{x}}=3.64, \mathrm{t}=11.863, \mathrm{p}<.05)$. Poor utilization of assets became the major barrier for entrepreneurs in Bihar.

Table 13. Management-related challenges

Source: Authors' compilation

\begin{tabular}{l|c:c:c:c}
\hline \multicolumn{1}{c}{ Problems } & Mean & t-value & Significance & Result \\
\hline $\begin{array}{l}\text { Poor utilization of } \\
\text { the assets }\end{array}$ & 3.57 & 14.828 & 0.05 & Rejected \\
\hdashline $\begin{array}{l}\text { Underutilization of } \\
\text { installed capacity }\end{array}$ & 3.06 & 1.336 & 0.18 & $\begin{array}{l}\text { Failed to } \\
\text { reject }\end{array}$ \\
$\begin{array}{l}\text { Inadequate material } \\
\text { management }\end{array}$ & 3.42 & 9.467 & 0.05 & Rejected \\
\hdashline $\begin{array}{l}\text { Absence of product } \\
\text { planning }\end{array}$ & 3.12 & 2.443 & 0.01 & Rejected \\
$\begin{array}{l}\text { Absence of } \\
\text { manpower planning }\end{array}$ & 3.14 & 2.851 & 0.00 & Rejected \\
\hline $\begin{array}{l}\text { Disputes among } \\
\text { partners }\end{array}$ & 1.91 & -19.810 & 0.00 & Rejected \\
\hline $\begin{array}{l}\text { Lack of market } \\
\text { research }\end{array}$ & 3.64 & 11.863 & 0.00 & Rejected \\
\hline
\end{tabular}

Note: Cronbach's alpha $=.704 ;$ Normality = Normal.

Other challenges. Table 14 shows that there are other problems namely natural disasters $(\overline{\mathrm{x}}=2.98$, $\mathrm{t}=-0.428, \mathrm{p}>.005)$, man-made calamities $(\overline{\mathrm{x}}=$ $3.49, \mathrm{t}=10.022, \mathrm{p}>.005)$, border disputes $(\overline{\mathrm{x}}=3.00$, 
$t=0.038, p>.005)$, domestic problems of entrepreneurs $(\overline{\mathrm{x}}=3.22, \mathrm{t}=4.101, \mathrm{p}<.005)$, and general recession $(\overline{\mathrm{x}}=3.54, \mathrm{t}=9.97, \mathrm{p}<.005)$. The paper concludes that market general recession became a cause of huge concern for MSMEs in Bihar.

Table 14. Other related challenges

Source: Authors' compilation.

\begin{tabular}{|c|c|c|c|c|}
\hline Problems & Mean & t-value & Significance & Result \\
\hline Natural disasters & 2.98 & -0.428 & 0.669 & $\begin{array}{l}\text { Failed to } \\
\text { reject }\end{array}$ \\
\hline Man-made calamities & 3.49 & 10.022 & 0.000 & Rejected \\
\hline Border disputes & 3.00 & 0.038 & 0.970 & $\begin{array}{l}\text { Failed to } \\
\text { reject }\end{array}$ \\
\hline $\begin{array}{l}\text { Domestic problems } \\
\text { of entrepreneurs }\end{array}$ & 3.22 & 4.101 & 0.000 & Rejected \\
\hline General recession & 3.54 & 9.97 & 0.000 & Rejected \\
\hline
\end{tabular}

Note: Cronbach's alpha $=.721 ;$ Normality $=$ Normal.

\subsection{Ranking of major variables}

Based on the findings it can be seen that MSMEs in Bihar have twelve major barriers that are ranked in Table 15. First, MSMEs argued that poor quality of roads is a major challenge faced by the owners/ managers to smooth movement of products and services in Bihar. Second, the electricity charges have been continuously increasing in the last few years. Third, MSMEs did not have proper access to public transport, which leads to an increase in the production and distribution cost of products. Fourth, the inadequate power supply forced to invest capital in other modes of power generators to reduce the gap of power supply. Fifth, the poor quality of the drainage system in Bihar ruins raw materials as well as products in the rainy season. Sixth, MSMEs blame that more dependency on private transport leads to higher amounts for the transportation of products. Seventh, poor marketing strategy creates severe problems for MEMEs. Eighths, MSMEs also admit that delayed payment received from the creditors affects their working capital management negatively. Ninth, MSMEs face a shortage of working capital. Tenth, MSMEs blame that lack of finance/crisis of finance have a high adverse impact on the purchase of raw materials. Eleventh, MSMEs also admitted that market recession makes it difficult to predict the demand for products necessary for business development. Twelfth, labor absenteeism complicates the process of employee hiring for owners/managers.
Table 15. Rank of major challenges

Source: Authors' compilation.

\begin{tabular}{|c|c|c|}
\hline Factors & Mean & Rank \\
\hline Poor quality of roads & 4.14 & 1 \\
\hline High electricity charges & 4.08 & 2 \\
\hline Lack of public transport & 4.05 & 3 \\
\hline Inadequate power supply & 3.96 & 4 \\
\hline $\begin{array}{l}\text { Poor quality of drainage } \\
\text { system }\end{array}$ & 3.96 & 5 \\
\hline High transport cost & 3.95 & 6 \\
\hline Poor marketing strategy & 3.94 & 7 \\
\hline $\begin{array}{l}\text { Delay in payment from } \\
\text { creditors }\end{array}$ & 3.87 & 8 \\
\hline $\begin{array}{l}\text { Shortage of working } \\
\text { capital }\end{array}$ & 3.84 & 9 \\
\hline $\begin{array}{l}\text { Lack of finance for raw } \\
\text { materials }\end{array}$ & 3.82 & 10 \\
\hline $\begin{array}{l}\text { Market recession/Lack of } \\
\text { demand }\end{array}$ & 3.74 & 11 \\
\hline Absenteeism & 3.73 & 12 \\
\hline
\end{tabular}

\subsection{ANOVA test}

ANOVA test is conducted to identify whether there were any variations in the responses for each category of barriers and variables in those categories of MSMEs, which have different socio-economic characteristics. Based on 12 categories of barriers, the study forms variations in the mean of responses based on their social characteristics and enterprise product specification, education, type of organization, ownership pattern, and gender.

Table 16 defines the relationship between independent variables (product specification, educational qualification, type of organization, ownership patterns, and gender) and dependent variables. The multivariate ANOVA test result has been processed with the test of homogeneity and the significance value of Levene's test being more than 0.05 . Further, the functional relationship between dependent and independent variables has been processed. By using the stepwise multivariate ANOVA test, it was shown that product specification and barriers do not have a significant relationship. Educational qualification and labor issues, competition problems have a significant relationship; further, gender has a positive significant relationship with 12 dependent variables.

To conclude, it is clear that problems are directly related to gender, hence it is obvious that gender biases have affected the MSMEs growth in Bihar. 
Table 16. Multivariate ANOVA test results

Source: Authors' compilation.

\begin{tabular}{|c|c|c|c|c|}
\hline Independent variables & Dependent variables & $\mathbf{F}$ & Significance & Conclusion \\
\hline \multirow{12}{*}{ Product specification } & Raw material challenges & 9.080 & 0.00 & Reject $\mathrm{H}_{0}$ \\
\hline & Financial challenges & 2.253 & .018 & Reject $\mathrm{H}_{0}$ \\
\hline & Labor challenges & 8.158 & .000 & Reject $\mathrm{H}_{0}$ \\
\hline & Technology challenges & 5.543 & .000 & Reject $\mathrm{H}_{0}$ \\
\hline & Power supply challenges & 4.118 & .000 & Reject $\mathrm{H}_{0}$ \\
\hline & Marketing challenges & 4.412 & .000 & Reject $\mathrm{H}_{0}$ \\
\hline & Infrastructure challenges & 2.437 & .010 & Reject $\mathrm{H}_{0}$ \\
\hline & Competition challenges & 9.412 & .000 & Reject $\mathrm{H}_{0}$ \\
\hline & Knowledge-related challenges & 3.295 & .001 & Reject $\mathrm{H}_{0}$ \\
\hline & Government and administrative challenges & 4.070 & .000 & Reject $\mathrm{H}_{0}$ \\
\hline & Management-related challenges & 4.249 & .000 & Reject $\mathrm{H}_{0}$ \\
\hline & Other challenges & 5.210 & .000 & Reject $\mathrm{H}_{0}$ \\
\hline \multirow{12}{*}{ Educational qualification } & Raw material challenges & 9.728 & .000 & Reject $\mathrm{H}_{0}$ \\
\hline & Financial challenges & 7.643 & .000 & Reject $\mathrm{H}_{0}$ \\
\hline & Labor challenges & .661 & .681 & Accept $\mathrm{H}_{1}$ \\
\hline & Technology challenges & 10.668 & .000 & Reject $\mathrm{H}_{0}$ \\
\hline & Power supply problem & 3.885 & .001 & Reject $\mathrm{H}_{0}$ \\
\hline & Marketing challenges & 3.661 & .001 & Reject $\mathrm{H}_{0}$ \\
\hline & Infrastructure challenges & 2.950 & .008 & Reject $\mathrm{H}_{0}$ \\
\hline & Competition challenges & 2.467 & .023 & Accept $\mathrm{H}_{1}$ \\
\hline & Knowledge-related challenges & 9.231 & .000 & Reject $\mathrm{H}_{0}$ \\
\hline & Government and administrative challenges & 4.592 & .000 & Reject $\mathrm{H}_{0}$ \\
\hline & Management-related challenges & 4.563 & .000 & Reject $\mathrm{H}_{0}$ \\
\hline & Other challenges & 4.093 & .001 & Reject $\mathrm{H}_{0}$ \\
\hline \multirow{12}{*}{ Gender } & Raw material challenges & .012 & .994 & Accept $\mathrm{H}_{1}$ \\
\hline & Financial challenges & .023 & .880 & Accept $\mathrm{H}_{1}$ \\
\hline & Labor challenges & .877 & .349 & Accept $\mathrm{H}_{1}$ \\
\hline & Technology challenges & .012 & .913 & Accept $\mathrm{H}_{1}$ \\
\hline & Power supply challenges & .186 & .667 & Accept $\mathrm{H}_{1}$ \\
\hline & Marketing challenges & .584 & .445 & Accept $\mathrm{H}_{1}$ \\
\hline & Infrastructure challenges & .211 & .646 & Accept $\mathrm{H}_{1}$ \\
\hline & Competition challenges & .001 & .975 & Accept $\mathrm{H}_{1}$ \\
\hline & Knowledge-related challenges & .264 & .608 & Accept $\mathrm{H}_{1}$ \\
\hline & Government and administrative challenges & 1.878 & .171 & Accept $\mathrm{H}_{1}$ \\
\hline & Management-related challenges & .206 & .650 & Accept $\mathrm{H}_{1}$ \\
\hline & Other challenges & .048 & .827 & Accept $\mathrm{H}_{1}$ \\
\hline
\end{tabular}

\subsection{Potential solutions}

MSMEs expect to get many solutions from the various stakeholders and government that could help to survive in the competitive global market. MSMEs respondents agree that government needs to facilitate industrial training and technical education to improve the quality of goods that are delivered from enterprises to the market. In Bihar, the legislative and regulatory problem is a major threat for the MSMEs. The legislative situation needs to be improved to foster the entrepreneurship; timely remedial actions are needed to solve the pending issues/files of the enterprises and enhance their potential. Furthermore, there should be a regular evaluation of programs to measure the performance and effectiveness of their program in helping SMEs.

MSMEs in Bihar faced poor quality of a road and transportation system, hence government should need to focus on road and transport development. In addition, it is vital to reduce financial problems and promote soft loan facilitation to MSMEs with a single-window clearance system for credit disbursement. MSMEs were facing completion with 
large firms; it requires taking positive steps to reduce the tax burden, licensing fee, effective tax policy, and increase their subsidies. To reduce the financial burden, the government can lower high electricity charges and install electricity in rural areas, which helps to create an effective environment for the MSMEs growth in Bihar. The government is expected to implement free and easy-to-access programs that will help SMEs to enter the global market (e.g. training on marketing skills and strategies, knowledge transfer, and entrepreneurial motivation). Policymakers are suggested to reduce the gender gap and promote women's entrepreneurship as they face huge problems beyond male entrepreneurs operating MSMEs in Bihar.

\section{CONCLUSION}

The study concluded that there are twelve major obstacles/barriers faced by MSMEs in Bihar, India: poor quality of roads, high electricity charges, lack of public transport, inadequate power supply, poor quality of drainage system, high transport cost, poor marketing strategy, delay in payments from creditors, shortage of working capital, lack of finance for raw materials, market recession/lack of demand, and absenteeism. In addition, it was found that gender inequality is a critical problem as many female entrepreneurs are highly affected by this obstacle.

Based on the primary investigation, many MSMEs hope that government effective policy could help to reduce barriers and problems. The expectation of MSMEs can be achieved through the high determination of the government towards creating a good governance environment. Through effective and good governance, the government can eliminate major obstacles for MSMEs. In the future, there is a need to focus on the migration of technical labor as it is a major hurdle for MSMEs, and it can be reduced through higher compensation and additional incentives to employees by MSMEs owners. Financial institutions and government may create high awareness towards loan policies, training programs, reduction in energy supply, and tax regulation policy, which will effectively enhance MSME functioning and timely delivery of products and services with a low level of corruption. Thus, the government should assist entrepreneurs through marketing opportunities, removal of barriers of labor laws, and financial subsidy, which will help them to come out from the barriers to run the enterprises in Bihar.

\section{AUTHOR CONTRIBUTIONS}

Conceptualization: Bishwajeet Prakash.

Data curation: Bishwajeet Prakash.

Formal analysis: Bishwajeet Prakash.

Investigation: Bishwajeet Prakash.

Methodology: Bishwajeet Prakash.

Project administration: Indrajit Kumar.

Resources: Indrajit Kumar, Jainendra Kumar Verma.

Software: Bishwajeet Prakash.

Supervision: Jainendra Kumar Verma.

Validation: Indrajit Kumar, Jainendra Kumar Verma.

Visualization: Indrajit Kumar, Jainendra Kumar Verma.

Writing - original draft: Bishwajeet Prakash.

Writing - review \& editing: Jainendra Kumar Verma. 


\section{REFERENCES}

1. Abushgra, A., \& Bach. (2013). Urban Planning Management. ASEE Northeast Section Conference reviewed paper. Norwitch University.

2. Acs, Z. J., Desai, S., \& Hessels, J. (2008a). Entrepreneurship, economic development and institutions. Small Business Economics, 31, 219-234. http:// dx.doi.org/10.1007/s11187-0089135-9

3. Acs, Z. J., Desai, S., \& Leora, F. K. (2008b). What does 'entrepreneurship' data really show? Small Business Economics, 31, 265-281. Retrieved from http://hdl. handle.net/10986/4902

4. Al-Hyari, K., Al-Naosur, M., Alnsour, M. S., Al-Wesnah, G., \& Abutayeh, B. (2011). Exporting Performance and Manufacturing Activities in Jordanian SMEs: External Barriers and Relationships. International Journal of Global Business, 4(1), 44-72.

5. Anderson, K., \& Pomfret, R. (2001). Challenges facing small and medium-sized enterprises in the Kyrgyz Republic, 19967. MOST: Economic Policy in Transitional Economies, 11, 205-219. http://dx.doi. org/10.1023/A:1013101026615

6. Ardic, P. O., Mylenko, N., \& Saltane, V. (2011). Access to Finance by Small and Medium Enterprises: A Cross-Country Analysis with A New Data Set. Pacific Economic Review, 17(4), 491-513. http:// dx.doi.org/10.1596/1813-94505538

7. Bala, M. H (2004). Small Industries and Globalization: Implication performance and Prospects. Economic Public Weekly, 34(18), 1826-1834. Retrieved from https:// www.jstor.org/stable/4414966

8. Baron, R. A., \& Shane, S. (2007). Empreendedorismo: Uma visão do processo. São Paulo: Thomson Learning. (In Portuguese).

9. Bartlett, W., \& Bukvic, V. (2001). Barriers to SME growth in Slovenia. MOCT-MOST: Economic Policy in Transitional Economies, 11,
177-195. Retrieved from https:// research-information.bris.ac.uk/ en/publications/barriers-to-smegrowth-in-slovenia

10. Beck, T., Demirguc-Kunt, A., \& Levine, R. (2005). SMEs, growth, and poverty: cross-country evidence. Journal of Economic Growth, 10(3), 199-229. https://doi. org/10.1007/s10887-005-3533-5

11. Benzing, C., Chu, H. M., \& Kara, O. (2009). Entrepreneurs in Turkey: A Factor Analysis of Motivations, Success Factors, and Problems. Journal of Small Business Management, 47(1), 58-91. https://doi.org/10.1111/j.1540627X.2008.00262.x

12. Bihari, S. C. (2011). Redefining MSME with CRM Practices. International Journal of Management \& Business Studies, 1(2), 49-55. Retrieved from http:// www.ijmbs.com/12/bihari.pdf

13. Blossom, C. A. N., \& Said, A. A. (2014). Challenges and barriers encountered by the SMEs owners in Muscat. International Journal of Small Business and Entrepreneurship Research, 2(3), 1-13. Retrieved from https://www.eajournals.org/ wp-content/uploads/Challengesand-Barriers-Encountered-By-theSMES-Owners-in-Muscat.pdf

14. Brace, I. (2008). Questionnaire Design: How to Plan, Structure and Write Survey Material for Effective Market Research (2nd ed.). London and Philadelphia: Kogan Page.

15. Chandraiah, M., \& Vani, R. (2014). The prospects and problems of MSMEs sector in India an analytical study. International Journal of Business and Management Invention, 3(8), 27-40. Retrieved from https:// www.ijbmi.org/papers/Vol(3)8/ D038027040.pdf

16. Chen, J. (2006). Development of Chinese small and mediumsized enterprises. Journal of Small Business and Enterprise Development, 13(2), 140-147. http://dx.doi. org/10.1108/14626000610665854

17. Choudhary, P. (2012). Financial Inclusion and Nationalised Banks Dhanbad District. Anusandhanika,
4(2), 177-181. Retrieved from https://www.proquest.com/ docview/1525427144

18. Confederation of Indian Industry (2019). MSMEs growth driven of Indian Economy. Proceedings of the Delhi SMEs Finance Summit. Resurgent India.

19. Das, B., Shil, N. C., \& Pramanik, A. K. (2007). Strengthening SMEs to make export competitive. Journal of Business and Technology, 2(1-2), 54-64. Retrieved from https://mpra. ub.uni-muenchen.de/7800/

20. Dasanayaka, S. W. S. B., Jayaratne, W., Rangajeewa, D. G. T., \& Sardana, G. D. (2017). Identification of Barrier for Development of the Sri Lankan Small- and Medium-scale Gem Mining Enterprises: A Case Study Based on Ratnapura District. South Asian Journal of Business and Management Cases, 6(1), 71-88. Retrieved from https://journals. sagepub.com/doi/abs/10.1177/227 7977917701594?journalCode=bmca

21. Gray, C. (2006). Absorptive capacity, knowledge management and innovation entrepreneurial small firms. International Journal of Entrepreneurial Behaviour \& Research, 12(6), 345-360. https://doi. org/10.1108/13552550610710144

22. Hair, J. F., Ringle, C. M., \& Sarstedt, M. (2011). PLS-SEM: Indeed a Silver Bullet. Journal of Marketing Theory and Practice, 19(2), 139-152. https://doi.org/10.2753/MTP10696679190202

23. Hamisi, S. (2011). Challenges and opportunities of Tanzanian SMEs in adapting supply chain management. African Journal of Business Management, 5(4), 1266-1276. Retrieved from https:// academicjournals.org/article/article1380621074_Hamisi.pdf

24. Hartungi, R. (2007). Understanding the success factors of micro-finance institution in a developing country. International Journal of Social Economics, 34(6), 388-401. https://doi. org/10.1108/03068290710751803

25. Hoque, A. K. M, \& Biswas, S. K (2014). Problems of sick industries 
- Bangladesh perspective. Journal of Mechanical Engineering, 43(2), 82-91. http://dx.doi.org/10.3329/ jme.v43i2.17831

26. Hussain, S. V. (2004). Performance of Small Scale Industries in India and the Challenges Ahead. Indian Journal of Industrial Relations, 39(3), 391-401. Retrieved from http://www.jstor.org/stable/27767913

27. Kambwale, J., Chisoro, C., \& Karodia, M. A. (2015). Investigation into the causes of small and medium enterprise failures in Windhoek, Namibia. Arabian Journal of Business and Management Review, 4(7), 80-109. Retrieved from https://www.arabianjbmr.com/ pdfs/OM_VOL_4_(7)/7.pdf

28. Kamunge, S. M., Njeru, A., \& Tirimba, I. O. (2014). Factors Affecting the Performance of Small and Micro Enterprises in Limuru Town Market of Kiambu County, Kenya. International Journal of Scientific and Research Publications, 4(12), 1-20. Retrieved from http:// www.ijsrp.org/research-paper-1214. php?rp=P363437

29. Kang, W. S. (2012). An identification of unsuccessful, failure factors of technology innovation and development in SMEs: A case study of components and material industry. International Journal of Business and Management, 7(19), 16-31. Retrieved from https://www.ccsenet.org/journal/index.php/ijbm/ article/view/17945

30. Krasniqi, B. A. (2010). Are small firms really credit constrained? Empirical evidence from Kosova. International Entrepreneurship and Management Journal, 6(4), 459-479. http://dx.doi.org/10.1007/s11365010-0135-2

31. Lawrence, J. E., \& Tar, U. A. (2010). Barriers to e-commerce in developing countries. Information, society and justice journal, 3(1), 23 35. Retrieved from http://repository.londonmet.ac.uk/id/eprint/88

32. Lokhande, M. A. (2014). Financial Inclusion Initiatives in India - A Review. Intercontinental Journal of Finance Research Review, 2(12), 22-33. Retrieved from https://www.
academia.edu/9988584/Financial_ Inclusion_Initiatives_in_India_A_ Review

33. Longenecker, J. G., Moore, C. W., \& Petty, J. W. (1997). Administração de pequenas empresas: ênfase na gerência empresarial. São Paulo: Makron Books. (In Portuguese).

34. Mali, D. D. (1998). Development of Micro Small and Medium Enterprises of India Current Scenarios and Challenges. SEDME Journal, 25(4).

35. Mallikarjunaiah, U., \& Sudarsan, K. (2012). Problems of Fishermen in Nellore District of Andhra Pradesh. Prabhadhan: Indian Journal Management, 5(7), 215-230. http:// doi.org/10.17010/pijom/2012/ v5i7/60228

36. Manzur, Q. S., \& Nayeem, A. M. (2009). Constraints to SMEs: A Rotated Factor Analysis Approach. South Asian Studies, 2(24), 334350. Retrieved from https://mpra. ub.uni-muenchen.de/26135/

37. McAdam, R., \& Reid, R. (2001). SME and large organization perceptions of knowledge management: comparisons and contrasts. Journal of Knowledge Management, 5(3), 231-241. http://dx.doi. org/10.1108/13673270110400870

38. Ministry of Micro Small and Medium Enterprises. (2006) Annual report. New Delhi, India: Government of India.

39. Ministry of Micro Small and Medium Enterprises. (2007). Quick result of fourth all India census. New Delhi, India: Government of India.

40. Ministry of Micro Small and Medium Enterprises. (2017). Annual report of NSSO Survey. New Delhi, India: Government of India.

41. Ministry of Micro Small and Medium Enterprises. (2018). Annual report of NSSO census. New Delhi, India: Government of India.

42. Mohammed, S. (2016). Bankruptcy prediction by using the Altman Z-score model in Oman: A case study of Raysut cement company Saog and its subsidiaries. Australasian Accounting Business and Finance Journal, 10(4), 70-80. http://dx.doi.org/10.14453/aabfj. v10i4.6

43. Moodley, S., \& Morris, M. (2004). Does e-commerce fulfils promise for developing country (South African) garment export producers? Oxford Development Studies, 32(2), 155-178. https://doi. org/10.1080/1360081041000169 9939

44. Mutula, S. M., \& Van Brakel, P. (2007). ICT skills readiness for the emerging global digital economy among small businesses in developing countries: Case study of Botswana. Library $\mathrm{Hi}$ Tech, 25(2), 231-245. https://doi. org/10.1108/07378830710754992

45. Nongnit, C. (2011). SMEs failure prediction: literature review. $A B A C$ Journal, 31(3), 70-81. http://www. assumptionjournal.au.edu/index. php/abacjournal/article/view/145

46. OECD. (2009). Development Cooperation Report 2009. https://doi. org/10.1787/dcr-2009-en

47. Olawale, F., \& Garwe, D. (2010). Obstacles to the growth of new SMEs in South Africa: a principal component analysis approach. African Journal of Business Management, 4, 729-738. Retrieved from https://academicjournals.org/ article/article1380715803_Olawale $\% 20$ and $\% 20$ Garwe.pdf

48. Olutunla, G. T., \& Obamuyi, T. M. (2008). An empirical analysis of factors associated with the profitability of small and mediumenterprises in Nigeria. African Journal of Business Management, 2, 195-200.

49. Omerzel, D. G., \& Antoncic, B. (2008). Critical entrepreneur knowledge dimensions for the SME performance. Industrial Management \& Data Systems Journal, 108(9), 1182-1199. https://doi. org/10.1108/02635570810914883

50. Parmar, S. S., Goswami, A., \& Sen, J. (2017). Economic Sustainability and Resilience of MSME sectors: Case of Traditional Craft Industries of West Mithila Region, Bihar. International Journal on Emerging Technologies, 8(1), 59-66. 
51. Pissarides, F. (1999). Is lack of funds the main obstacle to growth? Ebrd's experience with small and medium-sized businesses in Central and Eastern Europe. Journal of Business Venturing, 14(5/6), 519-539. https://doi.org/10.1016/S08839026(98)00027-5

52. Prakash, B. (2019). Growth and Performance of Micro, Small and Medium Enterprises in India: A Case Study of Bihar. Research Review International Journal of Multidisciplinary, 4(4), 942-947. Retrieved from https://rrjournals. com/past-issue/growth-andperformance-of-micro-small-andmedium-enterprises-in-india-acase-study-of-bihar/

53. Prakash, B., \& Verma, J. K. (2019). Barriers faced by entrepreneurs Micro, Small and Medium Enterprises in Bihar. In S. Mkisra, \& G. Batthini (Eds.), Biennial Conference on Entrepreneurship Entrepreneurs Development at the Institute Gandhi Nagar. New Delhi, India: Bookbell Publication.

54. Pribadi, H., \& Kanai, K. (2011). Examining and Exploring Indonesia Small and Medium Enterprise Performance: An Empirical Study. Asian Journal of Business Management, 3(2), 98-107. Retrieved from https://maxwellsci. com/print/ajbm/v3-98-107.pdf

55. Ramukumba, T. (2014). Overcoming SMEs Challenges Through Critical Success Factors: A Case of SMEs in the Western Cape Province. South Africa, Economic and Business Review, 16(1), 19-38. Retrieved from http:// ojs.ebrjournal.net/ojs /in dex.php/ ebr/article/view/338

56. Rao, P. V., Madhavi, N. B., \& Sivasree, V. M. (2015). Problems and Issues related to Working Capital Financing of Small and Medium Enterprises (SMEs) - A study of Andhra Pradesh. Proficient International Refereed Journal of Management, 2(2015), 19-28.

57. Reserve Bank of India (RBI). (2019). Annual Statistical Report. Retrieved from https://annualreport.rbi.org.in/
58. Salikin, N., Wahab, N., \& Muhammad, I. (2014). Strengths and Weaknesses among Malaysian SMEs: Financial Management Perspectives. Procedia - Social and Behavioral Science, 129, 334-340. https://doi.org/10.1016/j.sbspro.2014.03.685

59. Shaw, G., \& Williams, A. (2009). Knowledge transfer and management in tourism organizations: an emerging research agenda. Tourism Management, 30(3), 325-335. https://doi.org/10.1016/j.tourman.2008.02.023

60. Singla, A., \& Grover, P. (2012). Growth and Financing of MSMEs: A Case Study of Punjab and Haryana. Asia-Pacific Journal of Management Research and Innovation, 8(3), 315-321. https:// doi.org/10.1177\%2F231951 0X1200800311

61. Siringoringo, H., Prihandoko, Tintri, D., \& Kowanda, A. (2009). Problems Faced by Small and Medium Business in Exporting Products. Delhi Business Review, 10(2), 49-56. Retrieved from https://www.delhibusinessreview. org/e.pdf

62. Smallbone, D., \& Rogut, A. (2005). The challenge facing SMEs in the EU's new member states. International Entrepreneurship and Management Journal, 1(2), 219-240. https://doi .org/10.1007/ s11365-005-1130-X

63. Smith, M. H., \& Smith, D. (2007). Implementing strategically aligned performance measurement in small firms. International Journal of Production Economics, 106(2), 393-408. https://doi.org/10.1016/j. ijpe.2006.07.011

64. Smith, Y., \& Watkins, J. A. (2012). A literature review of small and medium enterprises (SMEs) risk management practices in South Africa. African Journal of Business Management, 6(21), 6324-6330. http://doi.org/10.5897/ AJBM11.2709

65. Stel, A. V., Carree, M., \& Thurik, R. (2005). The effect of entrepreneurial activity on national economic growth. Small Business Economics, 24(3), 311-321. https://doi.org/10.1007/s11187005-1996-6

66. Tambunan, T. (2009). Development and Some Constraints of SMEs In Indonesia. Center for Industry, SME \& Business Competition Studies, University of Trisakti. Retrieved from https://www.rieti. go.jp/jp/events/10100101/pdf/55_tambunan_paper_en.pdf

67. Temtime, Z. T., \& Pansiri, J. (2006). Perceived managerial problems in SMEs: evidence from Botswana. Development and Learning in Organizations, 20(5), 15-17. http://dx.doi. org/10.1108/14777280610687998

68. Thayumanavar, B., \& Kavitha, T. S. (2019). Coping Risks On Small Scale Industries-An Empirical Study On Pump and Motor Manufacturers in Coimbatore, Tamilnadu. Research Explorer, 7(2), 50-57. Retrieved from https://iaraindia.com/wp-content/ uploads/2019/03/10-COPINGRISKS-ON-SMALL-SCALE-INDUSTRIES-AN-EMPIRICAL.pdf

69. Torri, M. C. (2012). Innovative Farmer Institutions and Market Imperfections: New Opportunities and Challenges for the Ayurvedic Sector and Small-Scale Enterprises in India. Journal of Entrepreneurship, 21(1), 59-90. https://doi.org/10.1177\% 2F097135571102100103

70. Urbach, N., \& Ahlemann, F. (2010). Structural Equation Modeling in Information Systems Research Using Partial Least Squares. Journal of Informational Technology Theory and Application, 11(2), 5-40. Retrieved from https:// aisel.aisnet.org/jitta/vol11/iss $2 / 2$

71. Van Praag, M., \& Versloot, P. (2007). What is the value of entrepreneurship? A review of recent research. Small Business Economics, 29, 351-382. http:// dx.doi.org/10.1007/s11187-0079074-x

72. Weaver, M. K., \& Pak, J. (1990). Export behaviour and attitudes of small-and medium-sized Korean manufacturing firms. International Small Business Journal, 8(4), 59-70. https://doi .org/10.1177/02662426 9000800404 